\title{
ハチドリの羽ばたきを模した羽ばたき飛行機の研究
}

\section{Study on Ornithopter Imitating Hummingbird's Flap}

\author{
○学 村田 大征（富山大）正 佐々木 基文（富山大院）
}

Hiroyuki MURATA, University of Toyama, Gofuku 3190, Toyama, Japan Motofumi SASAKI, Graduate School, University of Toyama

\section{1. 緒言}

従来の飛行機なじは，揚力を得るためには前進し続けな ければならず，起伏が多い地形での超低空飛行は困難であ る。ホバリング (空中静止) や後退，急旋回等が可能にな るロボットを製作すれば，これが解決されると考えられる.

八チドリは連続したホバリングが可能な唯一の鳥であり， 後退, 急旋回も可能である。本研究は八チドリを模すこと でホバリング等を可能にするロボットを製作することを目 的とする.

ここでは，基礎実験について報告する。

\section{2. 八チドリの特徵}

八チドリが他の鳥と違うのは主に羽ばたき方であり，図 1 で示すように八チドリは翼を 8 の字の軌跡を描きながら 羽ばたかせている。その軌跡の中で翼を打ち下ろすときに 自分の体重の $3 / 4$ を支える力を生み出し，打ち上げるときに 自重の $1 / 4$ を支える力を生み出す。この比が昆虫と鳥の中間 に当たる(昆虫は打ち下ろしと打ち上げでの体重を支える割 合が $1: 1$ ，鳥は全て打ち下ろしのときに自分の体重を支え ている).

八チドリは，他の鳥と比べて翼平面形は高速で羽ばたく ために細く，小型の鳥なので短い翼になっている。

\section{3. 実験機 1 の製作と実験方法}

\section{1 実験機 1 の構想と設計}

上記のハチドリの翼の軌跡を踏まえ，その軌跡に近い動 きができる機構を考える。実験機で作る八チドリを模倣し た軌跡と実験機で作るその他の軌跡の揚力の違いを実験て 求める.八チドリの軌跡の利点を検証するために実験機 1 を製作する。

実験機 1 は図 2 のような形状で，上部がてこクランク機 構，下部が往復スライダクランク機構になっている. てこ クランク機構が円周に沿った摇動をし, 往復スライダクラ ンク機構がスライダに沿った直線の運動を行い，二つが合 わさって 8 の字の軌跡を作れるように製作する.

機構が描く軌跡は図 2 の右図のようにてこクランク機構 と往復スライダクランク機構を簡易に表し，作図によって 軌跡を導き出す。

てこクランク機構の寸法はハチドリの翼の迎え角 $110^{\circ}$ を参考にし，後で利用できるように $110^{\circ}$ で摇動するように リンク長の比をクランク：連接棒：てこ：連接棒（固定） $=7: 14: 10: 12$ にして設計を行い，最終的に実験機はクラ ンク : 連接棒: てこ: 連接棒 $($ 固定 $)=28: 56: 40: 48[\mathrm{~mm}]$ の長さにした。

往復スライダクランク機構ではクランクの長さの 2 倍の 長さがスライダの振幅になる。法は $\phi 25[\mathrm{~mm}]$ のプーリを 使用することにし，クランク長は $20[\mathrm{~mm}]$ とした。

以上の寸法で作図を行ない，導き出された軌跡は図 3 の 太線で示されるような 8 の字の軌跡を描いており，てこク ランク機構と往復スライダクランク機構間の取り付け角度

(図 2 中の $\theta$ ) を変化させることで 8 の字の交点の位置が

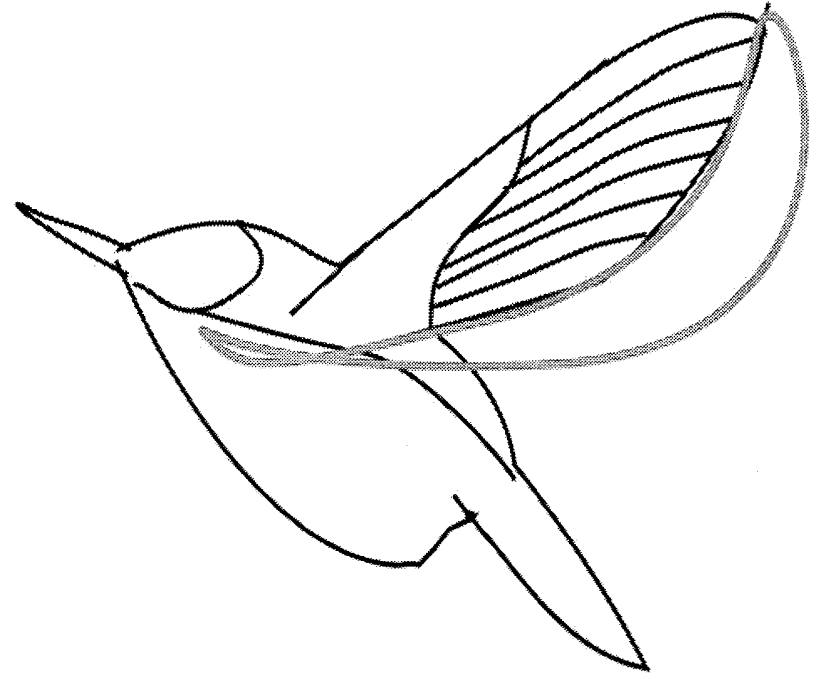

Fig.1 Trajectory of hummingbird's wing

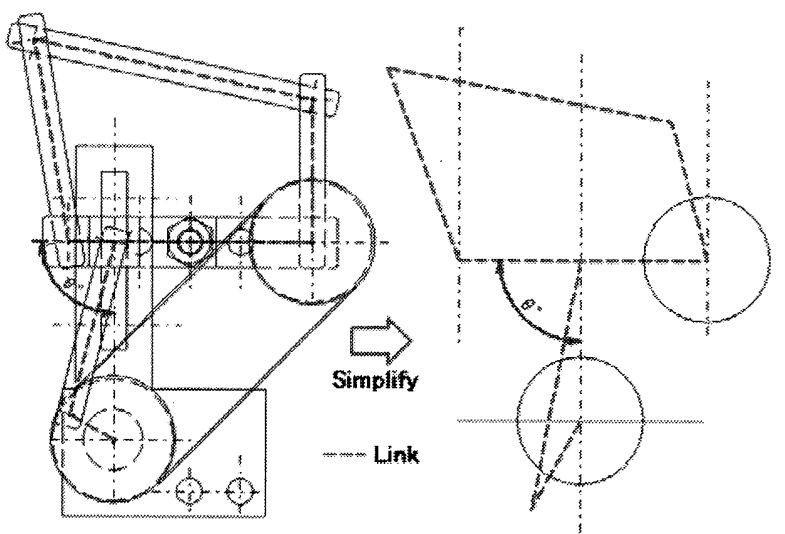

Fig. 2 Simplification of mechanism

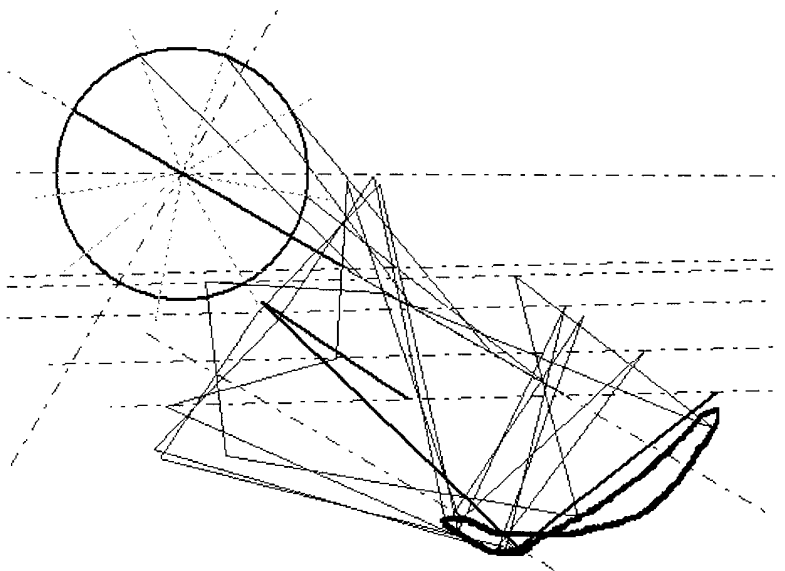

Fig. 3 Trajectory generated by the experimental machine 1 
ずれていくつかの軌跡を描く。図 3 の軌跡は取り付け角 $\theta$ $=60^{\circ}$ にしたときの軌跡で実際の八チドリと良く似た軌跡 を描いた。この軌跡をハチドリと類似した軌跡として，作 図によりシミュレーションを行なった機構を元に実験機を 製作した。

\section{2 測定装置の設計}

図 4 は実験機の水平方向及び垂直方向の空気力を測定す る装置である。これにより軌跡の違いによる空気力の変化 を測定する。

測定装置は空気力測定の実験に合わせて寸法等老決定し た。ひずみを検出する板は測定でかかる力を想定して，適 度なひず双が出るような片持らはりに法を決定してあり， 固定方法も片持ちはりとして計算できるように考慮して設 計を行なった。

\section{3 実験機 1 製作の結果及び考察}

実験機 1 の材料は強度に優れ，す心゙り性能がよいポリア セタールおよびスライダ部分には特にすべり性能が良い高 分子量ポリエチレンを使用し, 各部品をヒンジピンやボル 卜等でつなぎ，配置を変更しやすくすることで，何種類か の軌跡を出せるようにしておく。

実際に製作し駆動させ，その様子をカメラで撮影し画像 解析を行った。しかし，図からわかるように図 3 のような 8の字の軌跡は得られず，複雑で規則性が舆い軌跡になっ ている。これはプーリ同士の力の伝達に輪ゴムを使用した ことで軸閒距離の変化に対応することはできたが，ゴムの 伸び縮みにより 2 つのプーリの回転数の差が変化し，同期 できなかったのが原风である。

\section{4. 実験機 2 製作の結果及び考察}

実験機 1 で目的の軌跡を得られなった最大の理由は $2 つ$ のプーリ間の同期がうまくいかなかった点である。

そこでプーリ同上の同期性を高めるために，図6のよう なタイミングプーリ及びタイミングベルトを用い，改良し た実験機 2 を製作した。製作した実験機 2 を手動で動かし てみた場合，2つのプーリ閒の位相のずれは無くなり，常に 同じ軌跡を描くようになった。

しかし，軸間距離の変化に対する対応がベルト単独では 不可能になったため, 張り車を取り付ける必要が出てきた.

5. 結言

(1) シミュレーションによりてこクランク機構の円周に 沿った摇動と, 往復スライダクランク機構の直線の 運動を組合せることで 8 字の軌跡を描ける機構を作 れることがわかった。

（2）てこクランク機構と往復スライダクランク機構を組 合せ 8 字の軌跡を実際に生成するためには，2つの 機構を同期させる必要があることがわかった。

\section{文献}

[1] 田中光一, みんなで作ろうインドア・プレーン, (CQ 出版) , (2006), 149-172

[2] 和田康資・松雪公彦・河村良行・西本椧史, ”羽ばたき翼の空気力测定と翼膜の画像解析システム の開発” 福剛工羓大学河村研究室 (online), available from

$<$ http://www.fit.ac.jp/ y-kawa/packages/study/2007st/2007_ kaiseki02.pdf>, (accessed 2009-1-19)

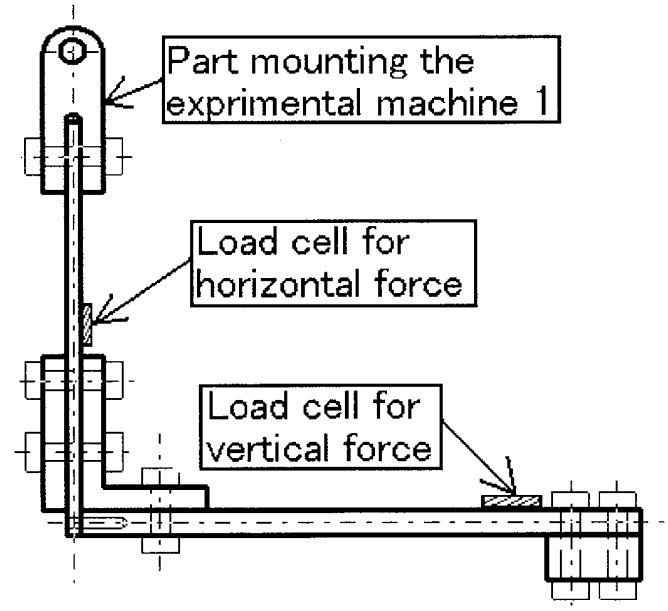

Fig. 4 Apparatus measuring forces

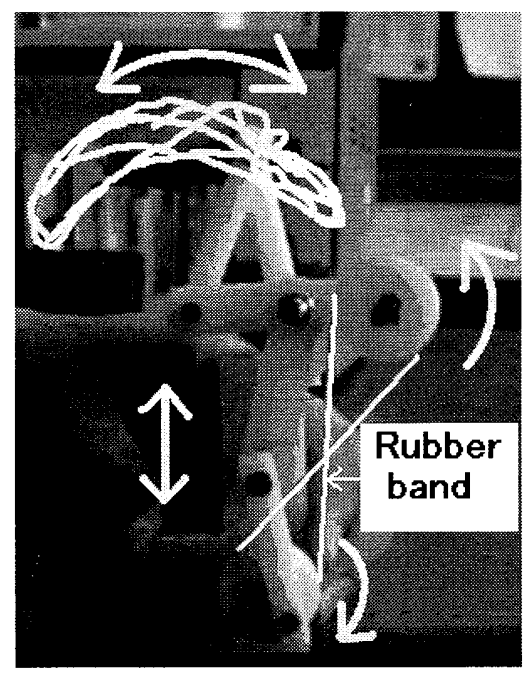

Fig.5 Outline and trajectory of the experimental machine 1

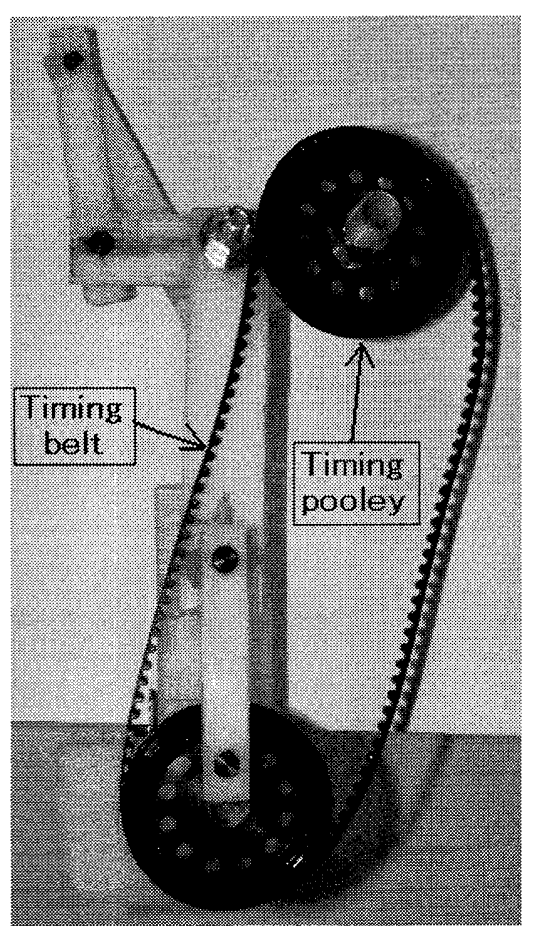

Fig.6 Improved experimental machine 2 